$\begin{array}{cl}\begin{array}{c}\text { Revue } \\ \text { de /histoire } \\ \text { des religions }\end{array} & \text { Revue de l'histoire des religions } \\ & \begin{array}{l}\mathbf{4} 2012 \\ \text { Varia }\end{array}\end{array}$

\title{
Robert Bellah on the origins of religion. A Critical Review
}

Robert Bellah et les origines de la religion

Guy G. Stroumsa

\section{(2) OpenEdition \\ Journals}

Electronic version

URL: http://journals.openedition.org/rhr/7976

DOI: $10.4000 /$ rhr.7976

ISSN: 2105-2573

Publisher

Armand Colin

Printed version

Date of publication: 1 December 2012

Number of pages: $467-477$

ISBN: 978-2200-92796-7

ISSN: 0035-1423

Electronic reference

Guy G. Stroumsa, "Robert Bellah on the origins of religion. A Critical Review », Revue de l'histoire des religions [Online], 4 | 2012, Online since 01 December 2015, connection on 30 April 2019. URL : http:// journals.openedition.org/rhr/7976 ; DOI : 10.4000/rhr.7976 


\section{Robert Bellah on the origins of religion A Critical Review*}

This book, as hefty as it is ambitious, represents the opus maximum of the great American sociologist of religion Robert Bellah. The author establishes his quest, from the 'big Bang' to Karl Jaspers' 'axial age,' in the middle of the first millennium B.C.E., upon Durkeimian and Weberian principles, and studies in turn the civilizations of Israel, of Greece, of India and of China. Doing this, he ignores Iran, and does not reach up to Christianity and Islam, which appeared later. The failure of the enterprise is at the level of its ambitions. It is an honorable one.

\section{Robert Bellah et les origines de la religion}

L'opus maximum du grand sociologue américain de la religion Robert Bellah est aussi imposant qu'ambitieux. Du «Big Bang» à la «période axiale » chère à Karl Jaspers, au milieu du premier millénaire avant notre ère, l'auteur, se fondant à la fois sur l'héritage de Durkheim et sur celui de Max Weber, tente de reconstituer la formation du champ religieux tel que nous le connaissons, à travers les civilisations d'Israël, de la Grèce, de l'Inde et de la Chine. Ce faisant, il ignore l'Iran et ne traite ni du christianisme ni de l'islam, apparus plus tard. L'échec de l'entreprise est à la hauteur de ses ambitions. C'est toutefois un échec honorable.

* Of: Robert N. Bellah, Religion in Human Evolution: From the Paleolithic to the Axial Age (Cambridge, Mass.: Belknap Press, 2011), XXX + 743 pages, ISBN 978-0-674-06143-9. 


\section{The QuesT}

In the very first sentence of his great Joseph saga, Thomas Mann referred to the unfathomable well of the past, into which one must plunge in order to reach back to the very roots of Israelite history and religion. In his turn, Robert Bellah, a distinguished American sociologist of the old, Weberian school, has taken the plunge in his opus maximum, but did not stop, like Mann, where history reverts to myth. In his epic search for the ultimate origins of religion, he kept falling much further down in time, up to... the Big Bang. Trying to climb back the well, Bellah does not quite make it to our own post-modern times, when religion has become again, after a long hibernation, something to be explored seriously, by scholars and scientists alike. Bellah's quest ends, more or less, with the so-called 'axial age' around the mid-first millennium B.C.E., an age of deep transformations for human societies, and hence for religion, encapsulating what is essential to religion as we know it today, in particular among the world religions. His book ends centuries before Jesus, a whole millennium before Muhammad. This choice may strike the contemporary reader as odd: a book offering a fundamental, historical (or should one say, meta-historical) reflection on religion in all human societies, which does not even touch the leading religious cultures of our world, through which emerged the main contemporary problems raised by religion, such as intolerance, violence and the intricate relationship with political power.

Religion in Human Evolution is a big book, with a number of big ideas, on a huge topic. In it, Bellah seeks to deal with the original kernel and early development of religion, from prehistory to antiquity. His leading principle, which informs the whole book, is that, as societies became more and more complex in human evolution, religions followed suit. Opting for the search of the deep roots rather than the analysis of the proximate channels through which the religions with which we are familiar emerged, Bellah starts with 'the building blocks' of religion, which go back beyond ritual, myth, and theology. For him, it is essential to recognize the essential role of play in the very formation of ritual: homo ludens, rather than homo sapiens, invents 
symbolic ways of expression. Ritual, for Bellah, is humanity's basic social act. Earliest, simple societies engaged in mimetic, wordless ritual. It is only after the emergence of tribes that cultures learned to organize themselves through narratives. In more complex tribal societies, we can follow the differentiation of powers in what had previously been rather egalitarian societies of gatherers-hunters.

Systems of class stratification and the emergence of priests and gods seem to appear for the first time, as for instance in Hawai or in Tikopia, a tiny island in the southern part of the Solomon Islands. Archaic societies, such as those of Egypt and Mesopotamia, were dramatically more complex than even the more developed tribal societies. We are dealing here with much bigger societies, in which the early states and civilizations emerged. The centralization of political power also had a major impact on religion, which had to offer a moral meaning to the king's power.

Seeking to identify the kernel of religion in the earliest human societies, he finds it in ritual, which he sees as directly related to the playing function of humans. For Bellah, it is the emergence of language among humans which entailed the birth of ritual and religion. He suggests that language brought with it the power to create symbols, a power directly related to religion. He makes use of the heteroclite arsenal provided by the latest trends in the various sciences, from physics and biology to the environmental and cognitive sciences. This is in itself legitimate, as intellectual breakthroughs are often made possible thanks to the application in a discipline of insights coming from another.

Yet, Bellah's attempt will strike many as speculative to the extreme: what kind of evidence, actually, do we have on the origins of humankind - and hence of religion? Such an argument is based upon the (fair) assumption that religion is to be found in all human societies, provided we define the term broadly enough. For most social scientists and scholars in the Humanities, certainly for those in the Anglophone world, 'speculation' almost always retains a negative aspect: what cannot be demonstrated should not be enunciated. Although many of the criteria according to which scholarship is now evaluated stem from the experiential sciences, it may not be quite a matter of chance if much of what may qualify as 'speculation' in Bellah's book comes from recent work in the brain sciences. In a sense, one can perceive this first part of Religion in 
Human Evolution (chapters one to five) as an essay in meta-science, a fundamental reflection going beyond the traditional disciplinary boundaries, making use of all possible intellectual ammunition in order to seek insights on the very roots of human existence.

Chapters six to nine deal successively with the civilizations of Israel, Greece, China and India, around the mid-first millennium B.C.E., in the classical formulations of religion in the 'axial age.' While in tribal societies, all were involved in ritual, in archaic societies public rituals focused around the king. The new political configurations had at once direct social consequences and a strong impact upon religious conceptions. This in its turn brought to a religious reaction against kingly aspects of public religion, and to important trends of de-ritualizing and de-mythologizing. In the case of Israel, the great prophets are the classical example of such a movement of religious protest, or revival. For the first time, religion would now incorporate ethics as an essential element. In Greece, the axial age was exemplified not so much with changes within religion as with the appearance of rational thought, speculation and wisdom. The early development of Greek paideia reflects this new attitude to the new intellectual and ethical universalism. Mutatis mutandis, a similar universalism is developed in Chinese aristocratic education, since the time of Confucius' Analects. Bellah insists that in the China of the warring states, ethical universalism is the measure of successful 'axial' transformation. As to Indian civilization, dharma, as the central ethicized term in the Upanishads, meets the criteria of ethicization. While this is true in the traditional Hindu culture, it becomes much more clearly observable with the birth and early growth of Buddhism. In all these cultural traditions, there would be, from now on, an ineluctable tension between the universalist trends in religion and ethics and the political environment.

It would be unfair to ask how much in that represents Bellah's original ideas and contribution to scholarship, on nothing less than an overview of the world's great cultures and their deep roots. What is perhaps more pertinent is to ask whether the reader is left with a new insight on the nature of religion in human societies, past and present. Rather than answering this question directly, however, I shall seek to unpack the genealogy of this book and its intellectual pedigree. 


\section{DURKHEIM's AND WebER's INHERITANCE}

Religion in Human Evolution appears just ninety-nine years after Emile Durkheim's The Elementary Forms of Religious Life was first published in the original French. During the century that has elapsed since the publication of Durheim's seminal book, there have been a number of major attempts to take religion seriously as a major phenomenon of humankind. These attempts stand out in a western world otherwise characterized by a lack of interest in religion on the part of too many leading intellectuals, who expected the demise of religion in modern societies. We have recently learned, the hard way, to accept the fact that religion is very far indeed from disappearing, in most societies throughout the globe.

While Durkheim is Bellah's main guide in his epic search for the origins of the universal phenomenon of religion, Max Weber is his master in all things pertaining to religion in ancient societies. Bellah deals with two major points in his book. Seeking to identify the kernel of religion in the earliest human societies, he finds it, following the American anthropologist Roy Rappaport (Ritual and Religion in the Making of Humanity [Cambridge, 1999]), in ritual, which he sees as directly related to the playing function of humans. For Bellah, as for Rappaport, it is the emergence of language among humans which entailed the birth of ritual and religion. Adding the insights of the cognitive scientist Terrence Deacon, author of The Symbolic Species: the Co-evolution of Language and the Brain (New York, 1997), Bellah suggests that language brought with it the power to create symbols, a power directly related to religion. In the first chapters, he reviews what can be called the 'building blocks' of religion: ritual and myth. He makes use of the heteroclite arsenal provided by the latest trends in the various sciences, from physics and biology to the environmental and cognitive sciences. Walter Burkert, the great historian of Greek religion, has sought throughout his career to find a genetic explanation for sacrificial practices, going back to Neolithic times. In his most ambitious attempt, Creation of the Sacred: Tracks of Biology in Early Religions (Cambridge, Mass., 1996), Burkert makes use of sociobiology, conscious of entering 'a battlefield.' Whether or not one is convinced by his argument, his readers must be impressed by Burkert's intellectual daring. 


\section{The Axial Age}

The analysis of the civilizations of Israel, Greece, China and India around the middle of the first millennium B.C.E., is the second, and to my mind the central focus in Religion in Human Evolution. This analysis is, of course, informed by Max Weber, but it is better described as the major effort to highlight, analyze and understand the nature of what has been dubbed since Karl Jaspers 'the axial age.' At the onset of The Origin and Goal of History, which appeared in the original German in 1949, the philosopher Karl Jaspers highlighted the fact, already noticed in the eighteenth century, that approximately around the mid-first millennium B.C.E., a series of exceptional figures appeared in a number of civilizations, which had a dramatic impact on thought and religion. Confucius and Mencius in China, the Buddha in India, Zarathustra in Iran, the Prophets of Israel and the Ionian Pre-Socratic philosophers all transformed the cultures in which they were born in radical ways (Zarathustra's dates are anything but certain. He may well have preceded the axial age by a few hundred years.). Jaspers was fascinated by this seeming synchrony, which he could not really explain. Neither did he, for that matter, offer detailed analyses of these cultural transformations. For Jaspers, the axial age constituted the great divide in human history. Civilizations before and after it were different in some fundamental ways. In Jaspers' perception, civilizations that had no obvious contacts between them underwent, at more or less the same time, which he called Achsenzeit (axial age), a spiritual 'quantum leap' which introduced self-consciousness and gave an ethical dimension to myths and to the perception of the universe. Through the spiritualization that this transformation involved, the axial age established the grounds on which the great historical religious and intellectual traditions emerged. In 1975, Jaspers' insight was picked up, as it were, by the participants of a special issue of Deadalus, the journal of the American Academy of Sciences, edited by the American Sinologist Benjamin Schwartz. The interest in the axial age recently gathered momentum with The Origins and Diversity of Axial Age Civilizations, a book edited in 1986 by the leading Israeli sociologist Shmuel Noah Eisenstadt. The current trendiness of the axial age is perhaps best highlighted 
by the publication, in 2006, of Karen Armstrong's The Great Transformation: The Beginnings of Our Religious Traditions.

The idea of the axial age, with its undertones of a scholarly approach emphasizing the spiritual unity of humankind and deep similarity between the 'great civilizations' and their intellectual and spiritual heroes, is easily seductive. This reviewer retains fond memories of exhilarating interdisciplinary seminars on 'axial civilizations' jointly taught with Eisenstadt and other colleagues in the early 1980s at the Hebrew University of Jerusalem: Eisenstadt (who died in 2010) urged us to dare dreaming, to speculate on the essence of the dramatic changes in patterns of thought and behavior as a consequence of the axial age. Play, indeed, is as essential an ingredient of intellectual creativity as it is of ritual. For him, the main axial transformation was the birth of cultural 'reflexivity' and of 'second order thought.' Thanks to the chasm that had opened between the heavenly world and the human realm, axial age cultures learned to express discursively their own cosmology and anthropology. This chasm also had another impact on religion, which now entailed a demand for salvation.

If I have insisted upon Eisenstadt's contribution, it is not only because of my personal recollections. It is, mainly, because Bellah himself had co-taught a course at Harvard, in 1963, together with Eisenstadt (and with Talcott Parsons), from which was born Bellah's seminal article on 'Religious Evolution' (1964). In this article, Bellah mentions neither Jaspers nor the Axial Age, but Weber's name figures prominently. Indeed, sociologists like Eisenstadt and Bellah saw themselves as walking in Weber's footsteps when they sought to compare ancient civilizations. Weber's Sisyphean attempt at highlighting the main articulations of societies, economics and religious views, from a comparative perspective, an attempt that was cut short by his death in 1920, remains to this day the most impressive and sustained effort to analyze religions in the context of the different societies in which they were born and grew, and the dialectical relationship between religion, economy and society.

In a sense, Religion in Human Evolution is the sequel to 'Religious Evolution,' a sequel which remained in gestation for almost half a century. This long gestation may partly explain why the book will more likely than not leave the reader with a sense that Bellah has overplayed his hand. Less, here, would probably have meant more. 
In 'Religious Evolution,' Bellah had identified five stages of religious evolution in human history: religion moved for him from 'primitive' to 'archaic' to 'historical' to 'early modern' to modern.' Religion in Human Evolution, however, does not deal with religion beyond the ancient world, although Bellah speaks of tribal, archaic, axial, post-axial, modern and post-modern stages. It remains unclear to me where exactly the axial age fits in Bellah's early taxonomy. I guess that the 'axial' and 'post-axial' stages correspond to the previous 'historic' stage. A certain lack of terminological clarity here prevents a clear-cut perception. But Bellah is not concerned by such 'details,' as crucial as they may be to the historian. What does concern him is the essential idea of 'evolution.' It is on purpose that he borrows this term from Darwin's historical physiology. Just as species evolve and eventually transform themselves, so do societies, and so do religions.

Like Durkheim, Bellah conceives the stages of religious development as following the evolution of societies moving from the less to the more complex. This Durkheimian trope is compounded by a Darwinian one: human evolution also belongs to the evolution of a species. Societies move from the simplest structures (the tribe) in the early stages of human history to more and more complex ones: the city, the early state, the empire. The transformations of society are accompanied by transformations of ritual, of myth, of religion. 'As societies became more complex, religions followed suit,' writes Bellah, indicating that such transformations are not linear. They are mainly accomplished through mutations, radical structural changes which appear to be the answer to crises and challenges. The axial age, he argues, witnessed a major crisis in the ritual system, as people stopped believing in the system's efficacy. Bellah can thus speak about a burst of 'anti-ritualism,' and of 'demythologization' (he uses here, in a new fashion, a concept coined by the theologian Rudolph Bultmann, referring to the mental activity necessary for a modern apprehension of the New Testament). To be sure, anti-ritualism does not entail the end of ritual, anymore than de-mythologization means the end of myth. It does point, however, to a new, critical attitude to traditional ritual, as well as to the new central importance of ethics in religion hence, the new universal dimension of religion. It is only with the break of former ritual systems that major breakthroughs could open new vistas in religious attitudes and beliefs. 


\section{A FAta MORGana?}

The fascination with the axial age reflects the similarity of intellectual and spiritual trends and culture heroes, across seemingly unrelated civilizations. This concept is a perfect antidote to accusations of Europeocentrism in an age of globalization. The problem is that the axial age seems to be a fata morgana. The riddle of synchrony evaporates at the mention of Akhnaton, Jesus or Muhammad, who should obviously belong to the club of 'axial' figures together with Socrates, Isaiah or Zarathustra. While it sometimes happens that different cultures reach a similar turning point at approximately the same point in time, what really counts, in each case, is the cause (or causes) of this turning point. Moreover, the obvious possibility of diffusionism should be entertained: if chariots and goods could move so easily, ideas could, too. But religious change can also be brought about by new technologies. The clearest case is probably that of the emergence and diffusion of script systems. The development of writing, which is directly related to the establishment of empires and huge, centralized societies, entailed the need, for the literate elites, to educate and train new generations of scribes, and eventually the redaction of books, and hence of holy texts, often remaining esoteric, not to be divulged to all and sundry. Religion inscribed in a book has become a portable religion, one that can and will travel. On various occasions in his book, Bellah points to the crucial importance of writing in the evolution of cultures, but fails to grant the topic all the focused attention it requires.

The concept of an axial age, then, is misleading. Rather than focusing on one epoch when everything, everywhere, tipped over, it is probably wiser to identify major cultural changes, whenever they happen. New configurations of culture and their social consequences are just as interesting as new configurations of society and their cultural consequences. Bellah's interest in early religion is no simple intellectual curiosity. For him, the axial age mutations are so significant because they would eventually shape our own world. More precisely, we are the inheritors, he says, of the legacy of both Greece and Israel. This may very well be the case, but it is only through the major intellectual remodeling effected by the Church Fathers (and before them by Philo of Alexandria) and of the 
Medieval Scholastic theologians (who could read Aristotle mostly thanks to the Arabs!) that these two legacies were integrated.

Scholarly attempts to deal with the foundations of the different disciplines are usually not crowned by success: since they cannot prove, they usually do not convince, and other scholars are prone to present detailed arguments refuting the main theses of the new theories. This is, to my mind, rather unfair. Failure, in such cases, is the price of aiming high. An intellectually ambitious work may not win approval in its discipline, but it often sets the tone for a whole generation of researchers, or more. There is such a thing as a respectable, even a noble failure, in the world of ideas.

If aiming high often entails missing the target, it also clearly points in the right direction. Bellah's book teaches us, once more, that religions should be studied in their different societal and cultural contexts. If there is no single homo religiosus, from all times and all cultures, as the phenomenology of Mircea Eliade wanted us to believe, that does not mean that there is no common ground between the rituals and myths of all nations. And if the axial age proves to be an illusion, that does not mean that religions, like societies, do not undergo at some turning points in history some major transformations, or even mutations. Analyzing such mutations in a comparative perspective, dismantling their inner mechanisms, is not merely possible. It is the key to a better understanding of the very nature of religious revolutions, past and present.

The challenge is how to dissolve false categories without giving up on the grand ambition to find laws, i.e. to retain the principle of unity beyond diversity - and what else is science, what else is scholarship? If the idea of the axial age fails to convince, it is not because there is 'nothing in it,' but because it is less unique and less universal than it claims to be. Rather than one single axial age, one might then prefer to speak of a number of axial periods, in each cultural eco-system- while it is possible, of course, to identify also some synchronic similarities between different cultural ecosystems. The longer late antiquity, for example, is such a period for the cultures of the Near East and of the Mediterranean. From Jesus to Muhammad, a series of religious movements (together with the Christians, one should mention, at least, the Rabbinic Jews, Gnostics, Manichaeans and Mandaeans) insist on the redaction and preservation of holy, revealed books. These books, which 
are often learned by heart, at least in part, are commented upon, sometimes translated, often sung during ritual. One can speak of a 'Scriptural movement' in the late antique Near East and Eastern Mediterranean. It is essential to understand how this new role played by books will soon transform the religious systems of the area, ushering in new configurations from the old building blocks (one may recall here Bellah's postulate that 'nothing gets lost' in the evolution of societies). These new religious configurations, namely Eastern and Western Christendom, as well as Caliphate Islam, will endure throughout the Middle-Ages. Since Bellah ends his quest before the formation of the religions we have recently learned to call Abrahamic, one is left with a strong sense of missing out what is most important for us to understand about religion. Religion in Human Evolution's broad strokes can only highlight the way. More delicate brushes will be needed now to unravel the various cases, from antiquity to the highly complex picture of religion in our postmodern, globalized societies, at once patiently and daringly.

guy.stroumsa@theology.ox.ac.uk 